\title{
Türkiye’de CBS Tabanlı Kömür Maden Bilgi Sistemi (KMBS) Kurulmasında Kullanılacak Bazı Kriterler
}

\author{
Some Criteria For Creating GIS Based Coal Mine Information System (CMIS) in Turkey \\ C. Bertan GÜLLÜDAĞ ${ }^{1} \mathbb{D}$, Mehmet ALTUNSOY ${ }^{2 *} \mathbb{D}$ \\ ${ }^{1}$ Akdeniz Üniversitesi Teknik Bilimler Meslek Yüksekokulu, Antalya \\ 2*Akdeniz Üniversitesi Mühendislik Fakültesi, Jeoloji Mühendisliği Bölümü, Antalya
}

Geliş (Received): 08 Mart (March) 2018, Düzeltme (Revised): 17 Mayıs (May) 2018, Kabul (Accepted): 05 Haziran (June) 2018

\section{ÖZ}

Maden Bilgi Sistemleri hem metalik hem de metalik olmayan madenleri kapsamaktadır. Fosil yakıtlar içerisinde ülkemizde en çok bulunan kömür için ayrı bir bilgi sisteminin oluşturulması, Türkiye'de madencilik açısından önemli katkılar sağlayacak bir çalışma olacaktır. Kömür Maden Bilgi Sistemi (KMBS) oluşturulmasında öncelikle potansiyel kömür sahaları belirlenip bu sahalara rezerv bilgilerinin işlenmesi gerekmektedir. Sahaların işletilme durumlarına göre tasnif edilmesinin ardından koordinat, detay rezerv, kurum, ruhsat gibi veri setleri işlenmelidir. Oluşturulacak sahalara jeolojik faktörler (birincil ve ikincil), çevresel faktörler, laboratuvar analiz sonuçları, insan sağlığı ve meslek hastalıkları riskleri, işçi sağlığı ve güvenliği verileri gibi veri setleri işlenmesi ile oluşturulacak tematik haritalar, istenildiğinde farklı kullanıcılar tarafından erişim ve analiz edilebilme avantajı sağlamaktadır. Coğrafi Bilgi Sistemlerinde verilerin güncel tutulması sistemin etkin kullanımı açısından oldukça önemlidir.

Anahtar Kelimeler: Bilgi Sistemi, CBS, Kömür, Maden

\begin{abstract}
Mine Information Systems contain both metalic and non - metalic mines. Amog fossil fuels, coal is commonly used one in Turkey and creating a different information system for the coal will provide important contribution from mining standpoint. For creating a Coal Mine Information System (CMIS), the first step is to establish potential coal fields and process reserve data of these fields. After the classification of the fields for management, coordinate, detail reserve, company and mining license should be added as data sets. These coal areas must have other data sets which are geological factors (primary and secondary), environmental factors, laboratory analysis results, risk of human health and occupational diseases. All of these data sets help to create thematic maps and the thematic maps can be used for access and analysis by different users. For the effective usage of the systems, these data must be current at all time.
\end{abstract}

Keywords: Information System, GIS, Coal, Mine 
Güllüdağ, Altunsoy

\section{GİRIŞ}

Türkiye fosil yakıt türlerinden biri olan kömür bakımından oldukça zengin bir ülkedir. Enerji ve Tabii Kaynaklar Bakanlığı'nın verilerine göre ülkemizde 2005 yılında 8.3 milyar ton olarak bilinen linyit rezervi 2015 y1lı itibariyle yeni bulunan sahalarla birlikte 15 milyar tonu aştı̆̆ 1 tahmin edilmektedir. Bilindiği gibi kömür termik santraller, sanayi, konut 1sitma gibi alanlarda yoğun olarak kullanılmaktadır. Gelişen teknoloji ile kömürün bulunduğu sahaları gösteren ve madencilik, çevre konularında risklerin tespit edileceği bir bilgi sisteminin kurulması işletilmekte olan sahalardaki Coğrafi Bilgi Sistemleri ile yapılacak çeşitli değerlendirme yöntemleri açısından ve ileriye dönük planlamalar için oldukça önemlidir. Son dönemde madencilik sektöründe yaygın kullanıma sahip Coğrafi Bilgi Sistemleri ile ekonomik açıdan oldukça verimli sonuçlara ulaşılmaktadır. Bu çalışmada kömür ve Coğrafi Bilgi Sistemleri (CBS) ile elde edilecek Kömür Maden Bilgi Sistemi (KMBS) oluşturulma aşamaları ve hangi kriterlerin göz önünde bulundurulabileceği gibi bilgiler yer almaktadır. Ayrıca kömürün içinde bulunan zararlı elementlerin veri setine işlenmesi ile kömür madenciliği, taşınması ve yakılması sırasında ortaya çkabilecek potansiyel tehlikelerin öngörülmesi, kurulacak bir termik santral ile yanacak kömürün çevreye verebileceği zararın tespit edilmesi anlamında da önemli katk1lar elde edilebilecektir.

$\mathrm{Bu}$ konu ile ilgili olarak ülkemizde yapılan çalışmalardan biri Seyis vd. (2002) tarafından gerçekleştirilmiş olup, Coğrafi Bilgi Sistemine dayalı jeolojik veri tabanı yöntemi ile oluşturulan lokal bir alan olan Zonguldak için çeşitli veri katmanları ve havzadaki kömüre ait çeşitli analiz sonuçları içeren bir veri tabanı hazırlanmıştır.
Ayrıca taş ocakları bilgi sistemlerinin kurulması örneğinde olduğu her maden türü için bu sistemler kurularak maden sahalarının kontrolü sağlanabilir (Ülger vd., 2006). Coğrafi Bilgi Sistemi çalışmalarının rezerv tespitinde kullanımında elde edilen sonuçların önceden tespit edilen gerçek rezerv sonuçlarına çok yakın olduğu bu hesaplamalarda kullanılmasının gerekliliğini ortaya koymaktadır (Doğan vd., 2007). Maden Bilgi Sistemi oluşturulması ile madenlerin rezerv bilgileri, işleten şirketler, sahada ortaya çıkabilecek hastalıklar ortaya konulabilir (Özkan vd., 2007). Uzaktan algılama metotları ve iki değişkenli istatistiksel yaklaşımlar neticesinde potansiyel kömür sahalarını tespit etmek mümkündür. Analizlerde formasyon, litoloji, faylanmaya mesafesi ve eğim gibi faktörler kullanılmıştır (Sütçü vd., 2009). Madende çalışan işçi sayıları, meydana gelen maden kaza sayıları, kazaların nedenleri ve sonuçları gibi unsurlar sisteme işlenmelidir (Şalap vd., 2009). Coğrafi Bilgi Sistemleri ile Maden Ruhsat Bilgi Sistemi oluşturulabilmektedir (Ac1, 2010). Madencilik faaliyetlerinde Coğrafi Bilgi Sistemlerinin kullanımında bir maden veri tabanı oluşturularak maden sahasındaki veriler buraya işlenebilmektedir (Dereli vd., 2010). Bu şekilde bir çalışma Güneydoğu Anadolu Bölgesinde Coğrafi Bilgi Sistemleri kullanılması ile sayısal maden haritaları oluşturularak yapılmıştır (Baran vd., 2016).

\section{KÖMÜR VE COĞRAFİ BİLGI SISTEMLERI}

Coğrafi Bilgi Sistemleri; konuma dayalı işlemlerle elde edilen grafik ve grafik olmayan verilerin toplanmas1, saklanmas1, analiz edilmesi ve kullanıcıya sunulması işlevlerini bir bütün halinde gerçekleştiren bir bilgi sistemidir (Yomralığlu, 2000). Gelişen teknoloji ile 
hem devlet kurumlarında hem de özel sektörde Coğrafi Bilgi Sistemlerinin kullanımı artmıştır. Özellikle madencilik faaliyetinde bulunan firmaların çalıştıkları sahaya ait elde ettikleri tüm verileri eski yöntemleri geride birakarak bu sistemlere işlenmesi Coğrafi Bilgi Sistemlerinin yaygınlaştığının bir kanıtı sayılabilir.

Tanımda da belirtildiği üzere Coğrafi Bilgi Sistemleri grafik veri (mekânsal veri) ve grafik olmayan verilerden (mekânsal olmayan verilerden) oluşmaktadır. Grafik veri; sondaj, maden sahası gibi mekânsal gösterimlere ait verilerden oluşurken, grafik olmayan veri sondaj koordinat1, kömürlü seviye, sorumlu mühendis, alınan numune derinliği, deney sonuçları gibi sayısal ve sözel verilerden oluşmaktadır (Şekil 1). suyu, eğim, paleontolojik bulgular gibi öznitelik verileri işlenebilir. Burada sahanın grafik olarak gösterimi kapalı bir poligon alan şeklinde düzenlenmesinin ardından işlenen öznitelik verileri ayrı bir tablo halinde verilecektir. Sondaj loglarının işlenmesinin ardından sahaya ait kömür ve litolojik birimlerin yorumlanmas1 safhasina gelinir.

$\mathrm{Bu}$ veriler doğrultusunda CBS'de kullanılan çeşitli yöntemler ile aradaki birimlerin tahmini, $\log$ korelasyonu yapılmış olunur. Yapılan sondajlar sonucunda korelasyon bilgileri test edilebilir. Sondajlara ait karot ve kesinti örneklerine yapılan Rock Eval, organik madde miktarı, organik madde tipi, HC potansiyeli, nem, kül, koklaşma, maseraller, parlaklık,

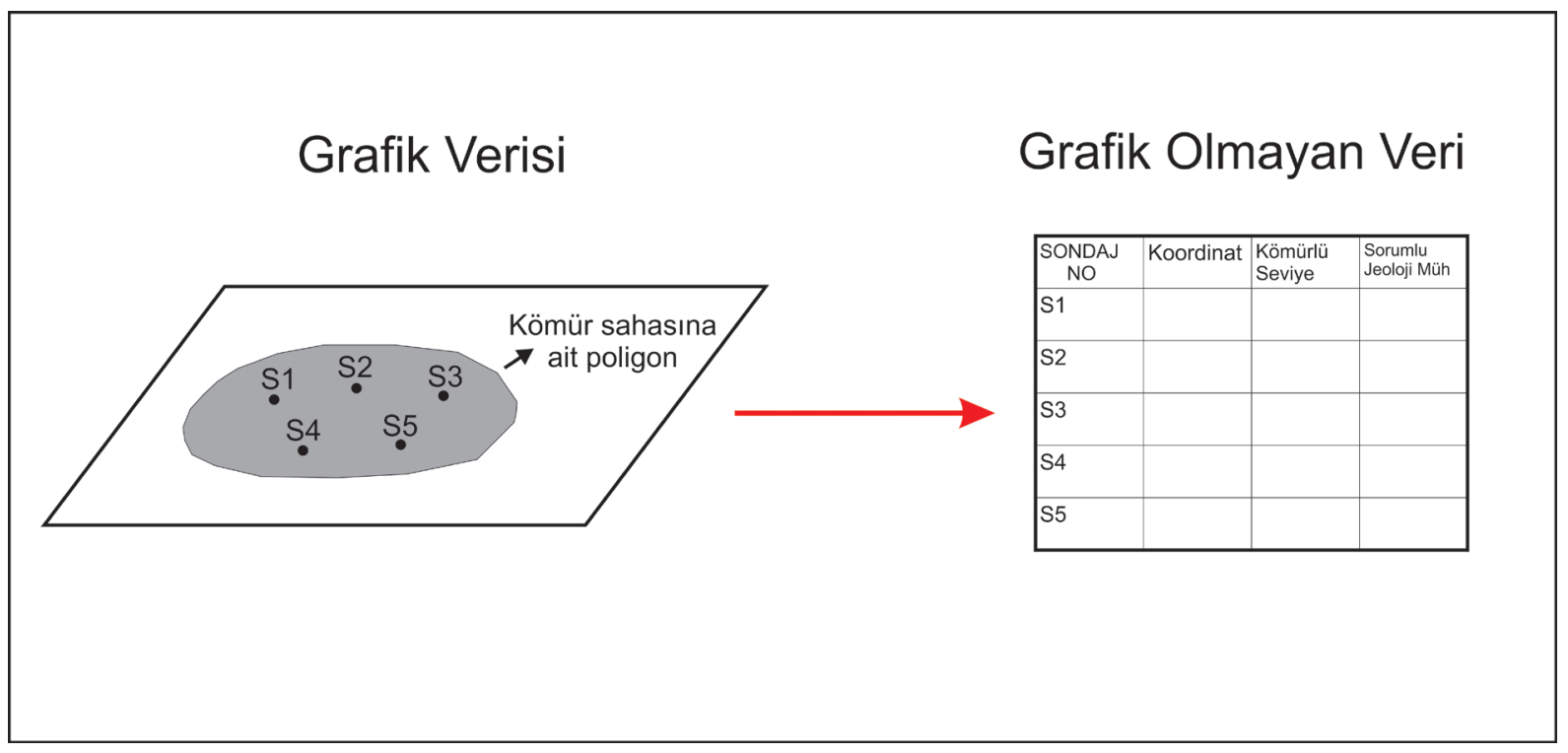

Şekil 1. Kömür sahalarında işlenebilecek grafik ve grafik olmayan veriler için örnek gösterim.

Figure 1. Illustration for graphical and non-graphical data that can be processed in coal fields.

Kullanıldığ1 alana göre değişim gösteren bu veri elemanları her kömür sahası için farkl11ık sunmaktadır. Örneğin bir kömür maden sahasinda rezerv tespiti yapılmasinın ardından bu sahaya ilişkin fay, litoloji, yeraltı sertlik gibi fiziksel ya da kimyasal olmak üzere tüm test sonuçları işlenebilir ve farklı simge ile gösterilebilir. Bunun sonucunda sahalar arası korelasyon yapılırken kömüre ait bilgilerin birlikte değerlendirilmesi sağlanabilir (Şekil 2). 
Güllüdağ, Altunsoy

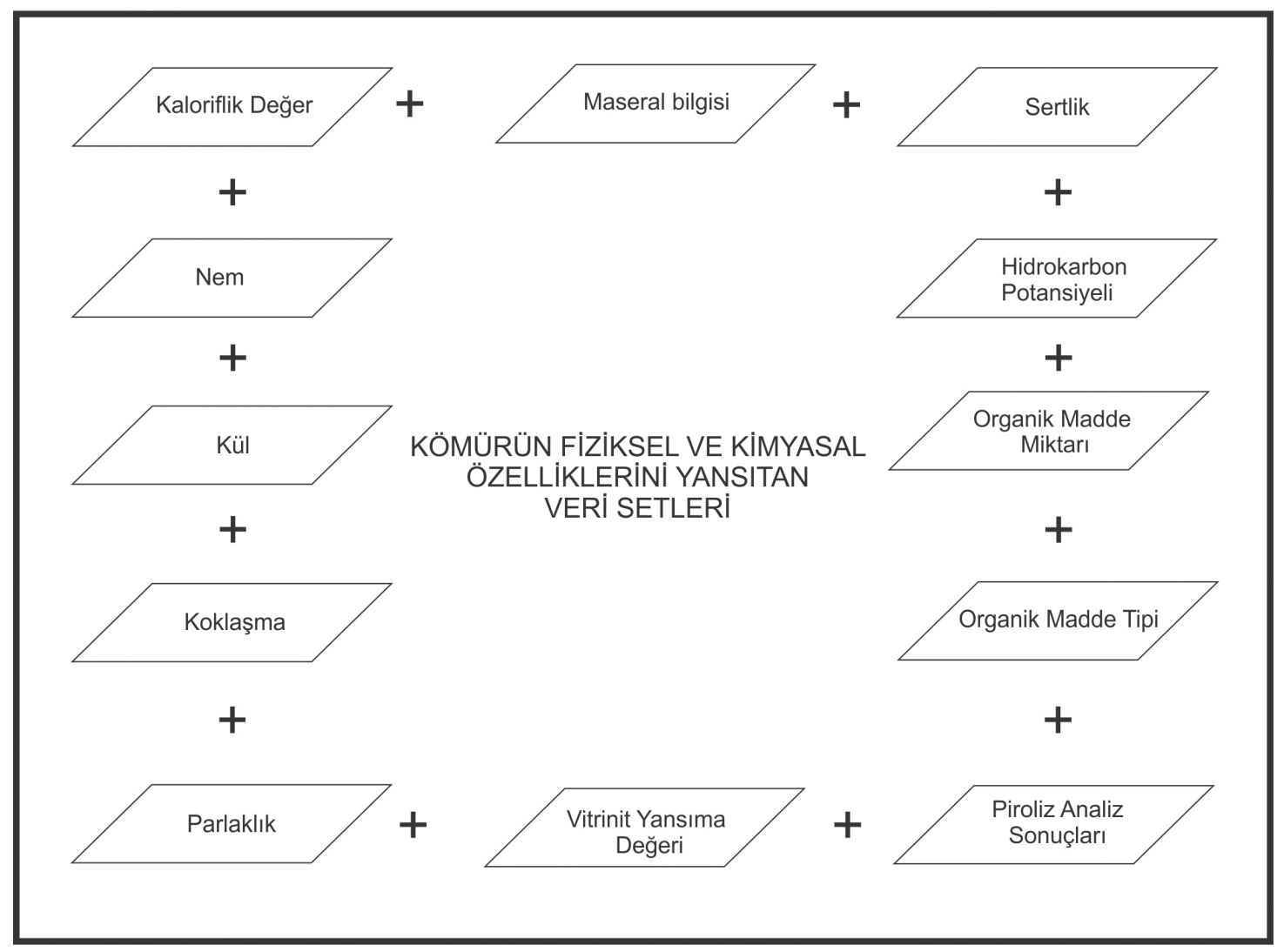

Şekil 2. Kömürün fiziksel ve kimyasal özelliklerinin oluşturduğu veri setleri.

Figure 2. Data sets of physical and chemical properties of the coal.

Coğrafi Bilgi Sistemlerini diğer programlardan ayıran en önemli fark sorgulanabilir olmasıdır. Sorgulama yöntemlerinden biri de yakınlık (buffer) analizidir. $\mathrm{Bu}$ çalışmada kömürün çevresel faktörler üzerindeki etkilerin incelenmesi yapıldığından sahaya ait konum verisine (poligona) en yakın su kaynakları, yeraltı su kaynaklarının derinlikleri gibi verilerin sorgulanmasının yanı sira taşınması sırasında meydana gelebilecek tahribat ve alternatif taşıma yolları belirlenebilir. Ayrıca kömürün yakılması sırasında ortaya çıkacak hava kirliliği ve yerleşim yeri karşılaştırmaları yapılabilir.
Şekil 3'de kömür sahalarının yakın çevresinde neden olabilecekleri zararların tespiti için kullanılan katmanların şematik gösterimi yapılmıştır. Buna göre bir kömür sahasının sınırları poligon şeklinde gösterilmiştir. Daha sonra bu sahada yapilan sondajların noktasal olarak konumlarının işlenmesinin ardından sahaya belli yakınlıkta bulunan ormanlık alanlar, drenaj hatları, yerleşim merkezleri, yollar ve yeraltı su seviyesi gibi birçok verinin işlenmesi ile çevresel açıdan sahanın yarattığı tahribatın önceden tespit edilmesi ve gerekli önlemlerin alınması sağlanabilir. Bu katmanları arttırmak ve çalışmayı amaca göre daha da detaylı hale getirebilmek mümkündür (Şekil 3). 

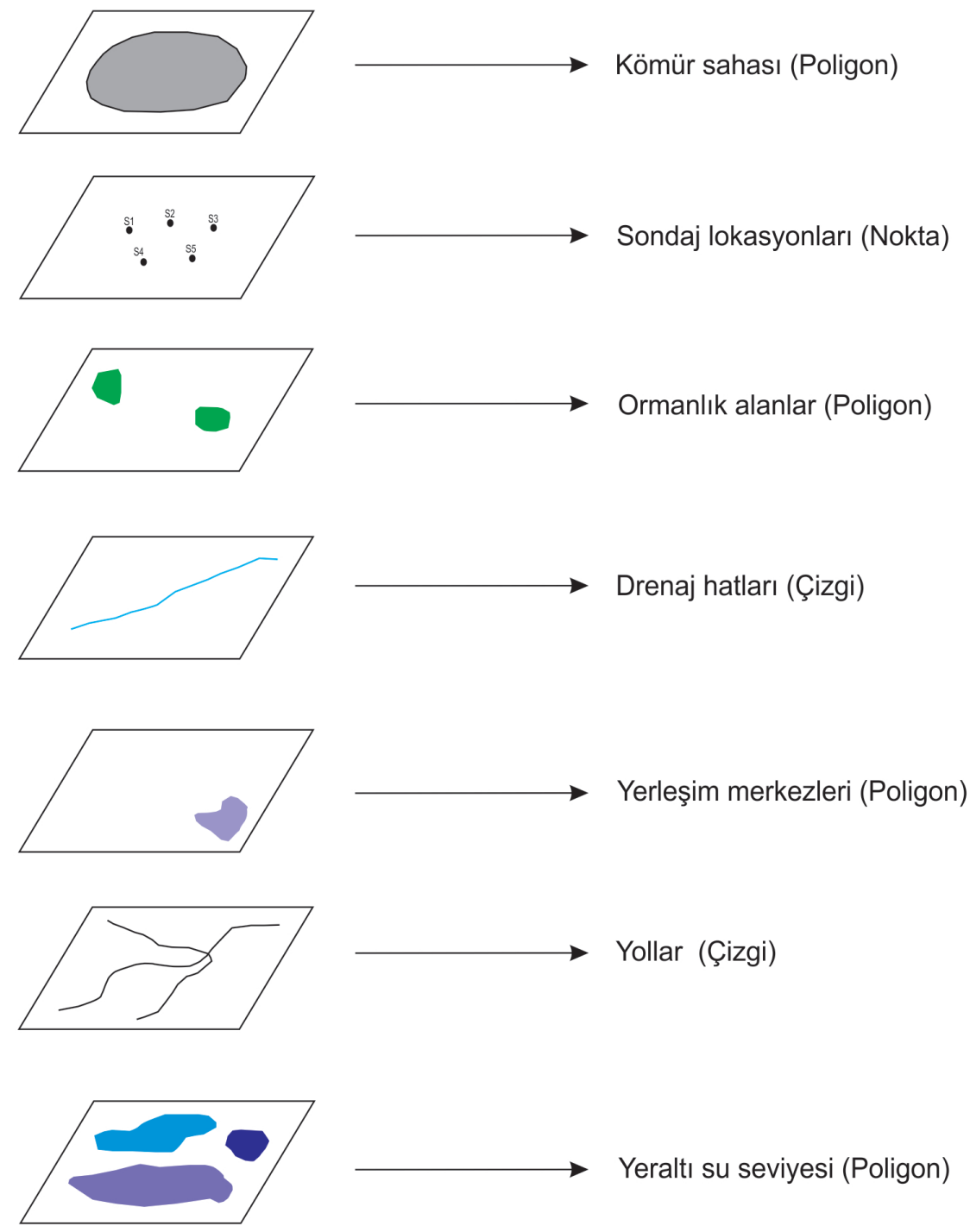

Yeraltı su seviyesi (Poligon)

Şekil 3. Kömür sahalarının CBS ile çevresel etkilerinin tespitinde kullanılabilecek katmanlar.

Figure 3. Layers that can be used to determine the environmental impacts of coal lands with GIS.

\section{KÖMÜR MADEN BİLGİ SİSTEMİ (KMBS)}

Maden Bilgi Sistemi; madencilik faaliyetleri sırasında ekonomik ve çevresel açından optimum kararlar verebilmek, maden faaliyetlerini o maden türü için bir bütünlük içerisinde irdelemek, madenlere ait konumsal ve konumsal olmayan verilerin ilişkilendirilip gerekli sorgu ve analizlerin yapılmasına olanak sağlayan Coğrafi 
Güllüdağ, Altunsoy

Bilgi Sistemi olarak tanımlanabilir (Özkan vd., 2007).

Kömür Maden Bilgi Sistemi; kömür ile ilgili tüm verilerin (ekonomik, çevresel, madencilik gibi) tek bir bilgi sistemine işlenmesi ile elde edilebilir. $\mathrm{Bu}$ verilerle özel haritalar oluşturulması, mekânsal ve mekânsal olmayan verilerin sistem üzerinde farklı kullanıcılarla sorgulatılabilme yetisinin bulunması bu sistemi gerek diğer maden bilgi sistemlerinden gerekse aynı madeni farklı sahalardan ayıran en önemli özellik olarak algılanabilir. Her maden sistemi için farklı kriterler önemlidir. $\mathrm{Bu}$ nedenle çalışma detaylandırılarak o maden sistemine ait daha ayrıntılı kriterler işlenmelidir. Böylece farklı maden sahalarından elde edilecek bilgi sistemlerinin birleştirilmesi ile oluşan genel bir maden bilgi sisteminin kurulması daha sağlıklı ve doğru sonuçlar bulunmasını sağlar.

Genel olarak oluşturulan Maden Bilgi Sistemi metalik ve metalik olmayan tüm madenlerin araştırılması ve haritalanmasına yöneliktir. Ancak, Kömür Maden Bilgi Sistemi sadece kömür ve kömür ürünlerinin aranmasından yakılmasına kadar her aşamada karşılaşılacak daha özel ve kömüre ait özelliklerin bu sisteme işlenmesini kapsamaktadır. Her aşamada farklı kullanıcıların erişebileceği bilgi sisteminin kurulması sonucunda etkin bir değerlendirme sağlanacaktır.

\section{Kömür Maden Bilgi Sistemi Oluşturulma Aşamaları}

Coğrafi Bilgi Sistemleri parçadan bütüne doğru her katmanın üst üste bindirilmesi ile elde edilen ve gerçek sistemi taklit eden bir modeldir. Oluşturulacak KMBS de kömür ile ilgili verilerin katmanlar şeklinde belirlenip üst üste bindirilmesi ile elde edilen bir bilgi sistemi olacaktır. Bu kapsamda her bir aşama bir katman olarak tespit edilmiş ve sırası ile yazılmıştır (Şekil 5).

\section{Kömür Sahalarının Yer Tespiti}

İlk aşama Türkiye'de bulunan kömür sahalarının tespitinin yapılmasıdır. Bu sahalar kömür ile ilgili genel sınırları oluşturacaktır. Detaylı bilgilendirme bu kapalı alanların (poligonların) içerisinde yapılacağ 1 için dış sınır olarak da nitelendirilebilir.

\section{Rezerv Tespiti}

Belirlenen sahalarda mümkün rezerv araştırmalarının yapılması ikinci aşama olarak belirlenmiştir. Sahaların işletilmesi açısından en önemli unsurlardan biri de rezervdir. Çizelge 1'de Türkiye'de bulunan linyit yatakları ve rezervleri yer almaktadır. 


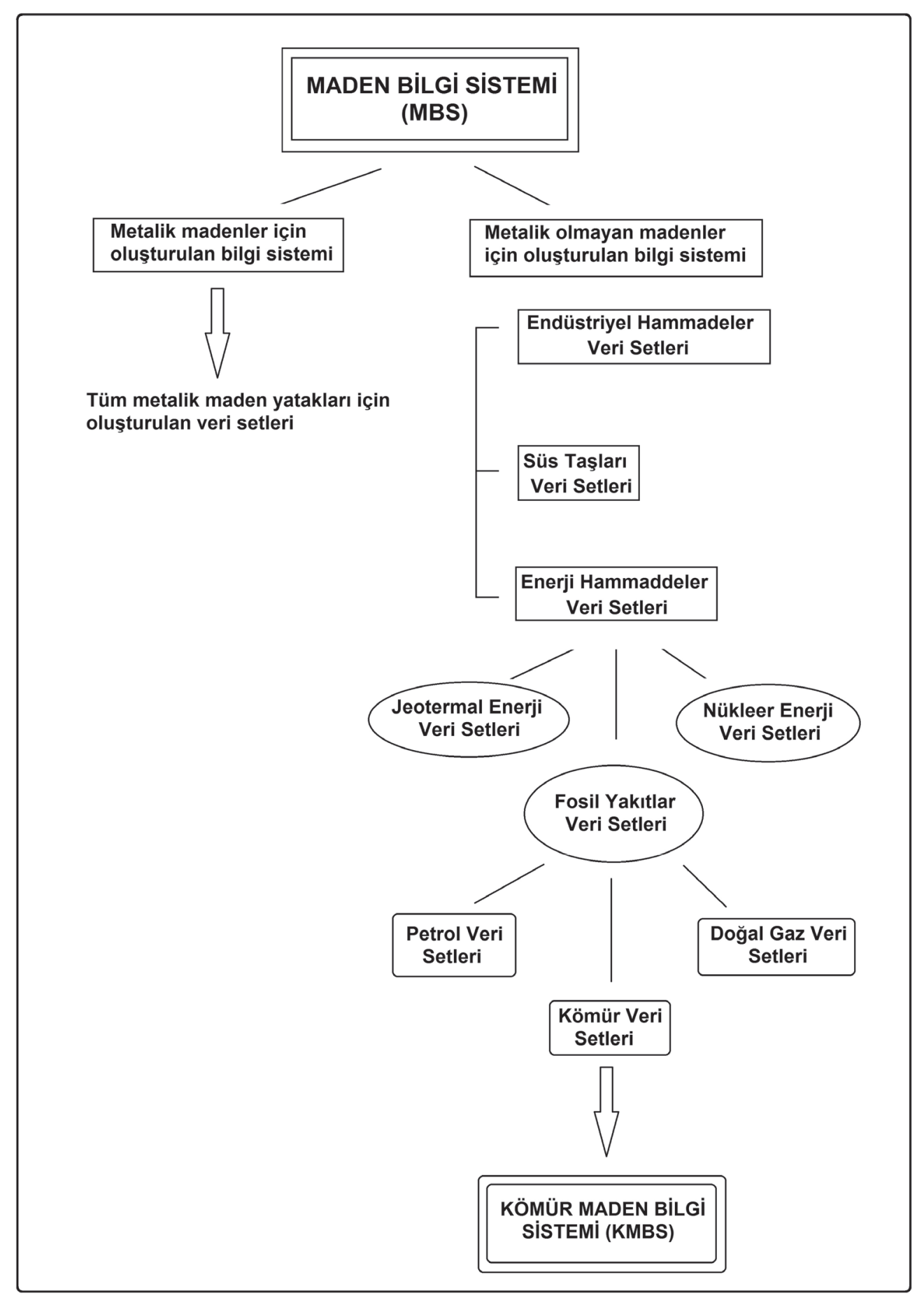

Şekil 4. Maden Bilgi Sistemi oluşturulmasında alt veri setleri ve KMBS ile ilişkileri.

Figure 4. Sub-data sets in the creation of the Mine Information System and relations with the CMIS. 
Güllüdağ, Altunsoy

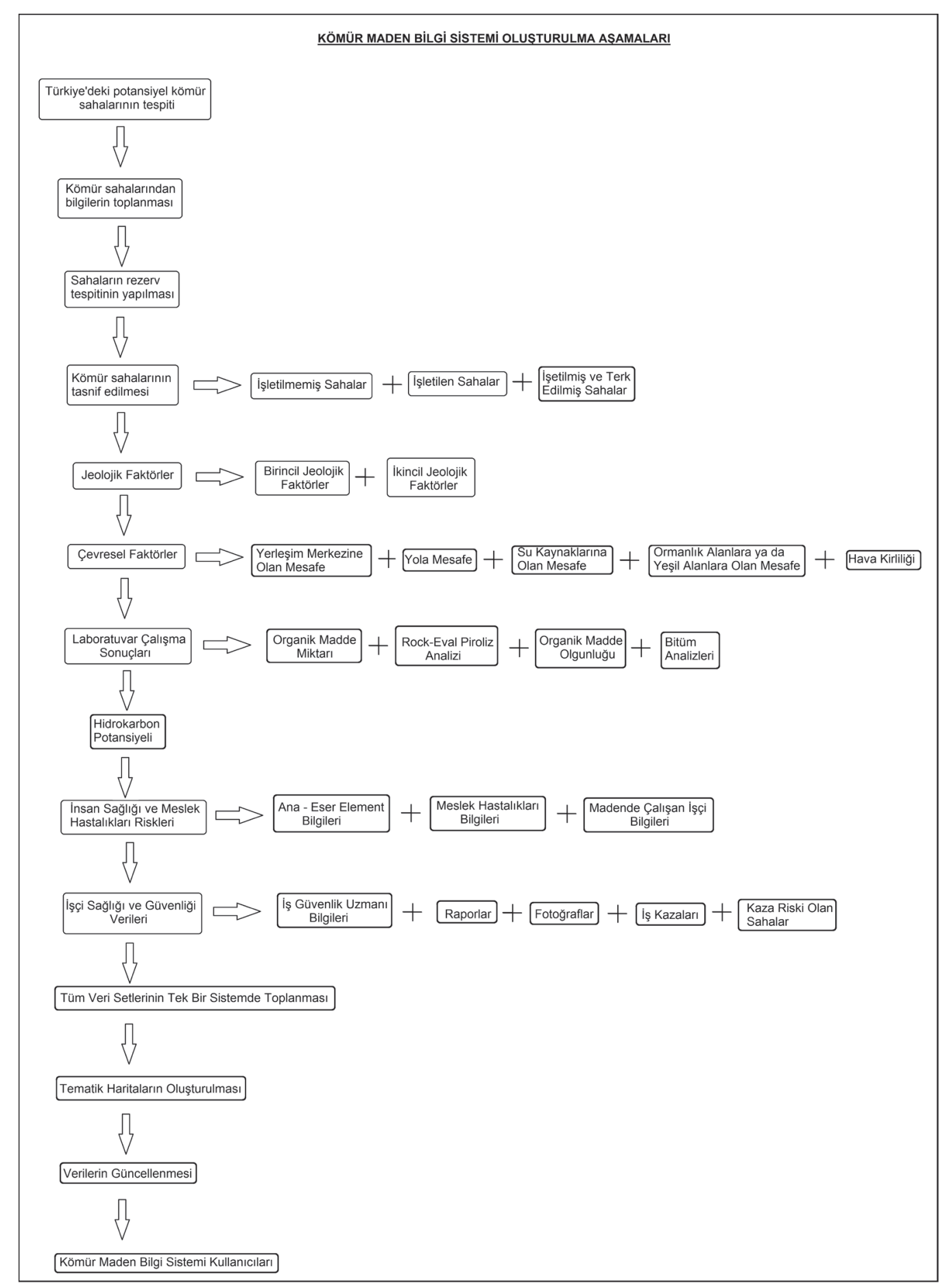

Şekil 5. KMBS oluşturulma aşamaları.

Figure 5. Stages of CMIS creation. 
Çizelge 1. Türkiye'deki kömür sahaları (MTA, 2010). Table 1. Coal fields in Turkey (General Directorate of Mineral Research and Exploration, 2010).

\begin{tabular}{|c|c|c|}
\hline Sira No & KÖMÜR SAHALARI & REZERV (ton) \\
\hline 1 & Afşin - Elbistan & 4.642 .340 .000 \\
\hline 2 & Afşin — Elbistan (MTA) & 515.000 .000 \\
\hline 3 & Manisa — Soma & 861.450 .000 \\
\hline 4 & Adana - Tufanbeyli & 271.302 .000 \\
\hline 5 & Adıyaman — Gölbaşı & 57.142 .000 \\
\hline 6 & Bingöl — Karlıva & 88.884 .000 \\
\hline 7 & Ankara-Beypazarı & 390.317 .000 \\
\hline 8 & Bolu - Mengen & 142.757 .000 \\
\hline 9 & Muğla - Milas & 750.214 .000 \\
\hline 10 & Çankırı - Orta & 123.165 .000 \\
\hline 11 & Çanakkale - Çan & 92.483 .000 \\
\hline 12 & Kütahya - Tunçbilek & 317.732 .000 \\
\hline 13 & Kütahya - Seyitömer & 198.666 .000 \\
\hline 14 & Sivas - Kangal & 202.607 .000 \\
\hline 15 & Kütahya - Gediz & 23.945 .000 \\
\hline 16 & Tekirdağ — Çerkezköy & 498.000 .000 \\
\hline 17 & Tekirdağ — Saray & 141.175 .000 \\
\hline 18 & Amasya - Yeniçeltek & 19.791 .000 \\
\hline 19 & Yozgat — Sorgun & 13.206 .000 \\
\hline 20 & Bolu — Göynük & 43.454 .000 \\
\hline 21 & Çorum — Dodurga & 38.500 .000 \\
\hline 22 & Konya - Karapınar & 1.230 .000 .000 \\
\hline 23 & Konya (Beyşehir-Seydişehir) & 348.000 .000 \\
\hline 24 & Bolu (salıp.-Merkez) & 98.000 .000 \\
\hline 25 & İstanbul (Silivri) & 180.000 .000 \\
\hline 26 & Eskişehir (Alpu) & 275.000 .000 \\
\hline 27 & Eskişehir (Koyunağıl11) & 57.430 .000 \\
\hline 28 & Edirne & 90.000 .000 \\
\hline 29 & Bursa (Keleş — Orhaneli) & 85.000 .000 \\
\hline 30 & Balıkesir & 34.000 .000 \\
\hline 31 & Ankara (Gölbaşı) & 48.000 .000 \\
\hline 32 & Diğerleri & 491.440 .000 \\
\hline 33 & TOPLAM & 12.419.000.000 \\
\hline
\end{tabular}

Linyit sahaları için Şekil 6'da örnek bir çalışma yapılmıştır. Türkiye'de bulunan linyit sahaları rezervleri ile birlikte programa işlenmiştir. Yapılan bu örnek çalışmanın diğer kömür tiplerine işlenmesinin ardından ayrı ayrı sahalara ait rezerv bilgisi elde edilebileceği gibi aynı türdeki kömürler için de güncel kömür rezerv verisine erişme olanağı sağlanacaktır.

Ayrıca bölgesel bazda yapilacak olan çalışmalar için kullanım imkânı sağlayacak olan bu sistem daha hassas çalışmalar için etkin sonuçların alınmasına olanak tanımaktadır. Şekil 7'de Tekirdağ ve civarında bulunan linyit sahaları için rezerv bilgisinin işlenmiş hali gözlenmektedir. Yapılması planlanan bölgesel çalışmalar için bu verilerden yola çıkarak daha hassas verilerin işlenmesinin ardından yerel olarak birçok verinin işlendiği veri birikimine sahip olmak ve bunlara ait sorgulamalar yap1lmas1 açısından oldukça fazla avantaj sağlayacaktır.

İl maden haritalarının sistem üzerinde koordinatlandırılarak sinırları belirlendikten sonra aynı jeolojik ortamlarda meydana gelmiş ve tespit edilmemiş maden sahalarının da ortaya çıkması sağlanabilir (Baran vd., 2016).

\section{Kömür Sahalarının Tasnifi}

Genel anlamda kömür sahalarının ve rezervlerinin belirlenmesinin ardından üçüncü aşama bu sahaların tasnif edilmesidir. Kömür sahasında rezerv ve kalori değerlerin yeterli olması ile burada işletme kurulması gibi bir durum tek başına yeterli olmayacaktır. İşletme kurulabilmesi için birçok kriterin sağlanması gerekmektedir. $\mathrm{Bu}$ niteliklerin takibini bir bilgi sistemi üzerinden sağlamak oldukça kolay ve verimli olacağı için, oluşturulacak olan Kömür Maden Bilgi Sistemine ek diğer faktörlerin eklenmesi oldukça önemlidir. Kömür sahalarını üç kısımda incelemek mümkündür. 
Güllüdağ, Altunsoy

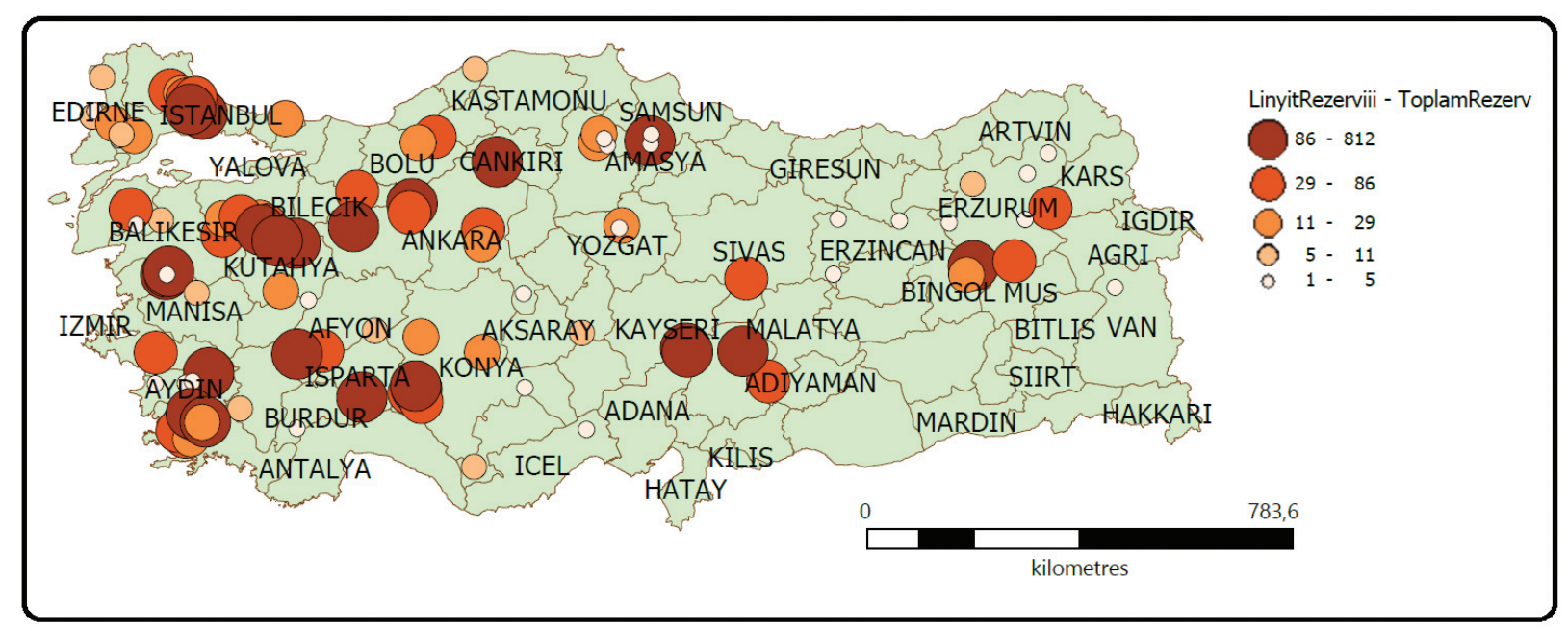

Şekil 6. Türkiye'de bulunan bazı linyit yatakları ve rezervleri.

Figure 6. Some lignite deposits and reserves in Turkey.

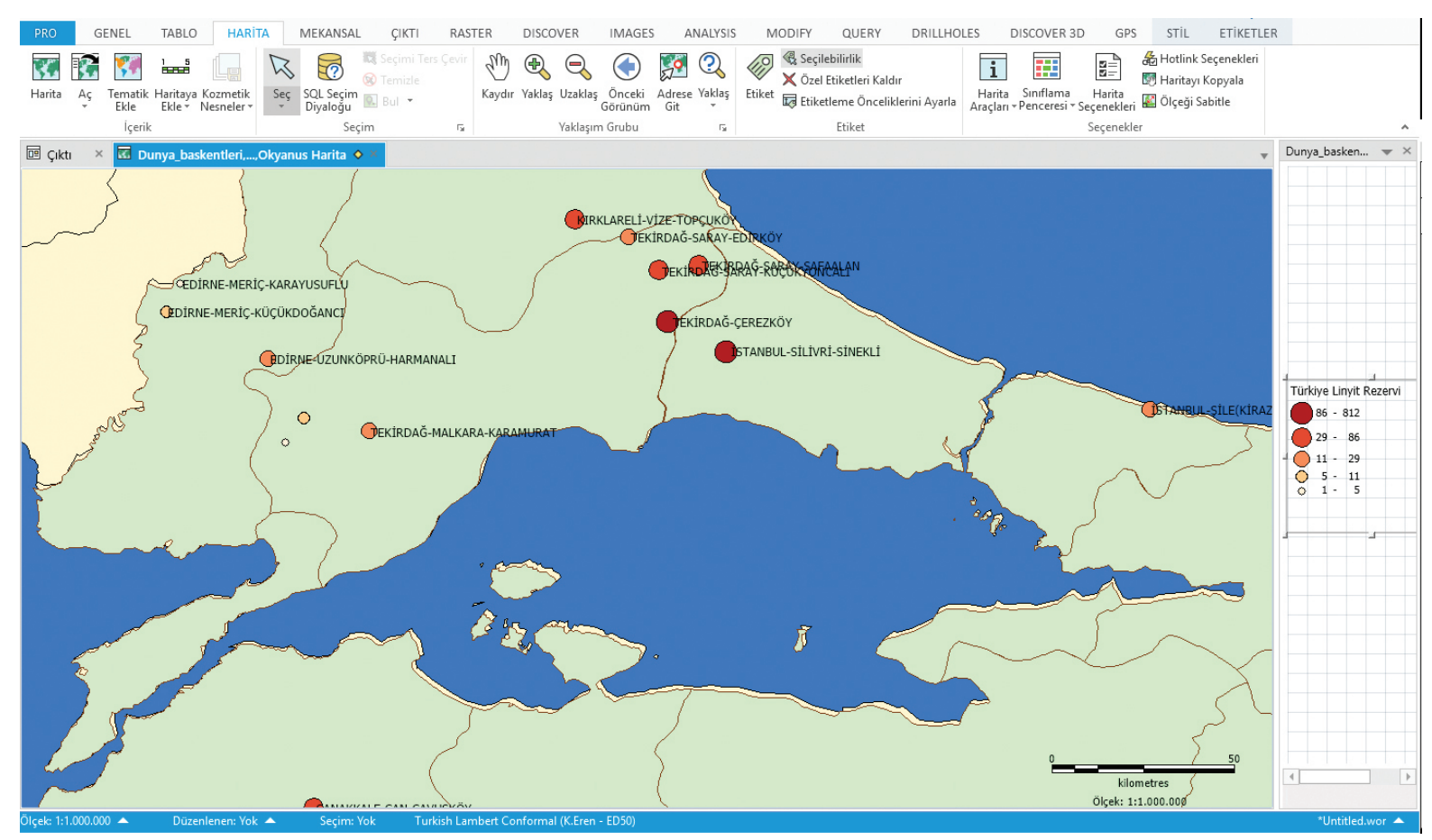

Şekil 7. Tekirdağ ve civarında bulunan linyit yatakları örnekleri ve rezervleri.

Figure 7. Lignite deposits and reserves in and around Tekirdă̆ district. 


\section{İşletilmemiş Sahalar}

Arama sondajları ile rezerv tespiti yapılması gereken sahalardır. Kısaca potansiyel kömür sahalarıdır. Böylece olası bir işletme kurulması durumunda saha hakkında karar vermek için doğruluk payı artacaktır.

\section{İșletilen Sahalar}

Arama sondajları ile çıkarılması ekonomik açıdan uygun görülen ve kömürün çıkarıldığ1 sahalardır. $\mathrm{Bu}$ sahalarda oluşturulacak bilgi sisteminde birçok veri seti işlemek mümkündür.

\section{İşletilen ve Terk Edilen Sahalar}

Kömürün çıkarıldıktan sonra işletmeci kurum veya kuruluş tarafından yeterli miktarda rezervin kalmamas1, maddi problemler ya da bürokratik bazı sorunlar nedeniyle sahadan ayrılması ile sonuçlanan sahalardır. Bu sahalarda genellikle yaşanan en büyük problem gerekli önlemlerin alınmadan sahanın terk edildiği durumlardır. Çizelge 2'de bu üç saha ayrımı için veri setleri yer almaktadır.

\section{Jeolojik Faktörler}

Kömür oluşumu ve çıkarılması sırasında birçok jeolojik faktör önemli rol oynamaktadır. $\mathrm{Bu}$ unsurlar ile ilgili jeolojik veri setlerinin oluşturulması diğer maden bilgi sistemlerinden ayıran en önemli faktör olacaktır. Jeolojik veri setlerini önem sırasına göre ikiye ayırarak işlenmesi daha doğrudur. Bu kapsamda jeolojik veri setleri Birincil Jeolojik Veri Seti ve İkincil Jeolojik Veri Seti olarak ikiye ayrilabilir.

\section{Birincil Jeolojik Veri Setleri}

Litoloji: Kömürün bulunduğu formasyonların ve bu formasyonların yaşlarının işlenmesi ile oluşturulacak olan veri setidir.

Fay: Kömürlü sahalarda bulunan fayların tespiti ve işlenmesi ile oluşturulacak veri setidir.

Yeraltı Suyu: Kurulacak kömür tesisinde yeraltı su seviyesinin bilinmesi işletme sırasında ortaya çıkabilecek sorunların ve galerilerde suyun oluşmasına yönelik alınacak tedbirlerin alınmasını sağlayan bir veri setidir.

Çizelge 2. Sahaların tasnif edilmesi ve veri setleri.

Table 2. Classification of the fields and data sets.

\begin{tabular}{|c|c|c|}
\hline $\begin{array}{c}\text { 1- ISSLETILMEMISS SAHALAR IÇĊN } \\
\text { VERİ SETLERI }\end{array}$ & $\begin{array}{c}\text { 2- ISSLETILEN SAHALAR IÇİN VERI } \\
\text { SETLERI }\end{array}$ & $\begin{array}{c}\text { 3- İŞLETILLMIŞ VE TERK EDİLMIŞ } \\
\text { SAHALAR İÇİN VERİ SETLERI }\end{array}$ \\
\hline Koordinat verisi & Koordinat verisi & - $\quad$ Koordinat verisi \\
\hline Poligon verisi & Poligon verisi & - $\quad$ Poligon verisi \\
\hline Eğim verisi & Eğim verisi & Eğim verisi \\
\hline \multirow[t]{4}{*}{ - $\quad$ Mümkün Rezerv verisi } & - $\quad$ Mümkün Rezerv verisi & - $\quad$ Mümkün Rezerv verisi \\
\hline & - $\quad$ Muhtemel Rezerv verisi & - $\quad$ Muhtemel Rezerv verisi \\
\hline & - $\quad$ İşleten kurum bilgi verisi & - Görünür Rezerv verisi \\
\hline & - $\quad$ Ruhsat verisi & - $\quad$ İşletmiş kurum bilgi verisi \\
\hline
\end{tabular}


Güllüdağ, Altunsoy

Eğim: Tabakaların ve sahanın eğim koşullarının sisteme işlenmesi ile elde edilecek veri setidir.

Paleontolojik Veriler: Litolojik birimlerde bulunan ayırtman fosillerin varlığı ile yaş tayini yapilmaktadır. $\mathrm{Bu}$ nedenle bulunacak fosillerin sisteme işlenmesi ile aynı birimlerin korelasyonu da kolaylaşacaktır.

Log Parametreleri: Sondaj loglarının çizilmesi ile elde edilen verilerin yorumlanmasıdır. İşletme sahalarında yapılan $\log$ verilerinin sisteme işlenmesi ile birçok bilgiye erişim sağlanabilir.

Arazi Modelleme: Bu çalışmalar ile sayısal yükseklik modelleri oluşturulmakta, arazi üç boyutlu olarak modellenmektedir.

Kaba Kimyasal Analiz: Kömürleşme derecesini etkileyen nem, kömür tamamen yandıktan sonra geriye kalan ve yanıcı olmayan kısım olan kül gibi faktörlerdir. Ayrıca kömürün kalori değerleri de bu veri setine dahil edilebilir.

\section{İkincil Jeolojik Veri Setleri}

Yapılan analiz sonuçlarının ve bazı jeolojik faktörlerin sisteme işlenmesi ve ilgili kullanıcılar tarafından ihtiyaç halinde kullanılmasını kapsayan veri setleridir. Fiziksel özellikleri ve kimyasal özellikleri ayrı ayrı yansıtan veri setleridir. Sistemin işlevsel hale getirilmesi durumunda aşağıda karışık olarak listelenmiş bu veri setlerini fiziksel ve kimyasal özellikler olarak iki ayrı başlıkta toplamak daha doğru olacaktır (Ünalan, 2010).
$\sqrt{ }$ Erozyon Risk Bölgeleri
$\sqrt{ }$ Porozite
$\sqrt{ }$ Özgül Ağırlık
$\sqrt{ }$ Koklaşma

$\sqrt{ }$ Oksidasyon

$\sqrt{ }$ Hidrojenasyon

$\sqrt{ }$ Çözücülerde Erime

$\sqrt{ }$ Hidrojenasyon

$\sqrt{ }$ Gaz Emme Özelliği (Adsorbsiyon)

$\sqrt{ }$ Sertlik

$\checkmark$ Ufalanabilirlik

$\sqrt{ }$ Öğütülebilirlik

$\sqrt{ }$ Grizu Riskleri

$\sqrt{ }$ Renk - Çizgi Rengi

$\sqrt{ }$ Parlakl1k

$\sqrt{ }$ Elektriksel Özellikler

$\sqrt{ }$ Yataklanma Tipi

$\sqrt{ }$ Maseraller

\section{Kömürün Çevresel Etkilerinin CBS ile Tespiti}

Fosil yakıtlar arama, çıkarılma, taşınma ve depolanma aşamalarında önemli çevresel tahribatlar yaratabilmektedir. Bunu tamamen önlemek mümkün olmayıp en aza indirmek ve bundan en az şekilde etkilenmesinin sağlanması olasıdır (Baba, 2000). Aşağıdaki veri setleri ile çevresel faktörlerin zararlarının indirgenmesi sağlanabilir.

Yerleşim Merkezine Olan Mesafe: Kömür sahalarının yakınında bulunan yerleşkelerin belli bir mesafede yakınına kömür işletmelerinin kurulmasının engellenmesi için oluşturulan veri setidir. $\mathrm{Bu}$ veri setleri ile buffer (tampon) bölge analizleri yapılabilir ve böylece insanların kurulacak maden tesisinden etkilenmesi engellenmiş olabilir. Türkiye'de ÇED (Çevre Etki Değerlendirmesi) hükümlerinin kömür için tespit ettiği yerleşim yerlerine uzaklık kriterlerinden faydalanılabilinir. 
Yola Mesafe: İşletme tesisleri kurulmasından sonra bu kömürün taşınması sırasında meydana gelebilecek olan yol tahribatlarının tespiti için elde edilen veri setidir. Bu kriteri tespit etmek zor olduğu için Karayolları ile ortak çalışmalar yapılabilir. Ayrıca maden sahalarının yola uzak olması maden taşımacılığında ek maliyetler doğurduğundan özellikle büyük işletmeler için yol çalışmaları ve revizyonlarının tespitinde de bu analizler kullanılabilir.

Su Kaynaklarına Olan Mesafe: Kömür işletmelerinin göl, akarsu, baraj, gölet gibi su kaynaklarına olan mesafesi tampon bölge analizleri sonucunda zarar görme potansiyeli olan alanların belirlenmesi açısından fayda sağlayacak bir veri setidir.

Ormanlık ya da Yeşil Alanlara Olan Mesafe: Kurulacak olan maden sahasinin ormanlık alanlara ya da yeşil alanlara belli bir mesafede olması kömürün çıkarılması ve taşınması sırasında oluşacak olan çevresel tahribatın en aza indirilmesi açısından önemli bir veri setidir.

Hava Kirliliği: Özellikle kömürün yanması sırasında ortaya çıkacak olan hava kirliliğinin belirlenmesi açısından hava kirlilik haritalarının elde edildiği veri setidir.

\section{Laboratuvar Çalışma Sonuçları}

Fiziksel ve kimyasal özelliklerin tespit edilmesinin ardindan sahalardan arama sondajları sonucunda alınan numunelerden yapılan laboratuvar deneyleri kömür ile ilgili oldukça önemli veriler sunacaktır. $\mathrm{Bu}$ amaçla aşağıda yapılan analizler ile veri setleri hazırlı̆̆ yapılan çalışmalara 1şık tutacaktır.

Organik Madde Tipi: Organik madde tipinin belirlenmesi ile elde edilen veri setidir.
Organik Madde Olgunluğu: Organik madde olgunluğunun tespiti ile elde edilen bu veri setinde hangi tür ürünlerin oluşacağının tespit edilmesi mümkündür.

Hidrokarbon Potansiyeli: Potansiyel verim parametresinin işlendiği veri setidir.

Bitüm (Özüt) Analizleri: $\mathrm{Bu}$ analizler sonucunda organik madde tipi, olgunluğu, çökel ortam özellikleri, biyolojik bozunma gibi bilgilerin olduğu veri setleridir.

İnsan Sağlığı ve Meslek Hastalık Riskleri

Ana - Eser Elementler: İnsan sağlığ açısından zararlı elementlerin belli sınır değerlerin altında olması gerekir. Türkiye kömürleri için belirlenen sınır değerler ile karşılaştırma yapılarak risk haritaları çıkarılabilir (Palmer vd., 2004). Bunun yanı sıra dünya kömürleri sınır değerleri ile karşılaştırma yapmak da mümkündür (Ketris ve Yudovich, 2009). Kömürün çıkarılması, taşınması ve yakılması sırasında ortaya çıkacak olan bu elementler hastalık yapıcı gibi olumsuz etkileri de bulunmaktadır. Bu element değerlerinde risk görülen bölgelerin işlendiği veri setidir.

Meslek Hastalıklarl Bilgileri: Kömür işçilerinde ortaya çıkan Pnömokonyoz, Slikosiz gibi hastalık bilgilerinin sisteme işlenmesi ile oluşturulan veri setidir.

Madende Çalışan İşçi Bilgileri: Haritalar üzerine işlenen sahalarda, işletilen tesislerde çalışan tüm çalışanların ve işçilerin bilgilerinin işlendiği öznitelik verileridir.

\section{IŞS Sağlı̆̆l ve Güvenliğ i:}

Maden sahaları birinci dereceden risk sınıfina giren işletmelerdendir. Kömür madenleri galeri ve açık işletme sistemi ile işletildiği için oldukça risklidir ve meydana gelen göçükler ile işçiler hayatını kaybetmektedir. Özellikle galerilerde 
Güllüdağ, Altunsoy

oluşan grizu, iyi havalandırılmayan madenlerde ortaya çıkan patlamalardır. Kömür depolarında meydana gelen yangınlar da insanların ölümüne neden olan başka bir unsurdur (Malkoç, 2010).

Bütün bu olayların önüne geçebilmenin en etkin yolu doğru bir kontrol mekanizması kurmaktır. Bu amaçla kurulacak İşçi Sağlığı ve Güvenliği veri seti ile iş sağlı̆̆ ve güvenliği uzmanı adı, tutulan raporlar, fotoğraflar, gibi veriler tek bir sistem altında işlenebilir.

$\mathrm{Bu}$ veri setinde aşağıdaki bilgiler yer almalidir.

$$
\begin{array}{cl}
\sqrt{ } & \text { İş güvenlik uzmanı bilgileri } \\
\sqrt{ } & \text { Raporlar } \\
\sqrt{ } & \text { Fotoğraflar } \\
\sqrt{ } & \text { Meydana gelen iş kazaları } \\
\sqrt{ } & \text { Kaza riski olan sahalar } \\
\sqrt{ } & \text { Madende çalışan işçi bilgileri }
\end{array}
$$

\section{Verilerin Sisteme İşlenmesi ve Haritaların Oluşturulması}

Öncelikle işlenecek mekânsal veriler ile kömür sahalarının konumlarını, sınır alanlarını belli eden haritalar hazırlanacaktır. Ardından elde edilen tüm bilgilerin işlenmesi ile öznitelik verileri oluşturulacaktır.

\section{KMBS Kullanıcıları}

Kömür maden bilgi sistemini birden çok kullanıcının kullanması ve buna göre farklı bilgilere erişim sağlaması gerekmektedir. Devlet kontrol mekanizması kurularak maden firmalarının tüm bilgileri sisteme işlemesi zorunlu hale getirilebilir. Kömür; arama, çıkarılma, taşınma, depolanma ve yakılma aşamaları geçiren bir fosil yakıttır. Her bir aşamada farklı kriterlerin bulunması, bu sistemin kurulmasında farklı kullanıcıların birbirinden bağımsız ya da ortak bazı bilgilere ulaşmasını gerektirmektedir. Bu nedenle her bir aşama farklı şekilde değerlendirilmelidir.

\section{SONUÇ VE ÖNERILER}

Maden Bilgi Sistemlerinin bir alt kolu olarak oluşturulan Kömür Madeni Bilgi Sistemi kömürle ilgili detaylı bilgiler sağlayacak bir bilgi sistemidir. $\mathrm{Bu}$ şekilde veri setlerinin belli bir düzen ve sıra içerisinde işlenmesi gerekir. KMBS' de ilk olarak kömür potansiyel sahaları tespit edilmeli ve bu sahalardaki rezerv bilgileri işlenmelidir. Potansiyel kömür sahalarının tespitinden sonra sahaların tasnif edilmesi ve buna bağlı olarak veri setlerinin işlenmesi gerekmektedir. Bir sonraki aşamada kömür ile ilgili detay veri setleri işlenmelidir. Veri setlerinin tamamının işlendiği bilgi sisteminde tematik haritalar oluşturulmalı ve analiz edilebilmelidir. KMBS; kömürün arama, çıkarılma, taşınma, depolanma ve yakılma aşamaları ile ilgili kullanıcıları kapsar ve bu kullanıcılara filtrelemeler yapmak için olanak sağlar.

\section{KATKI BELİRTME}

$\mathrm{Bu}$ makaleyi değerlendiren hakemlere katkılarından dolayı teşekkür ederiz.

\section{KAYNAKLAR}

Acı, Z., 2010. CBS tabanlı maden ruhsat bilgi sistemi oluşturulması. Dokuz Eylül Üniversitesi Fen Bilimleri Enstitüsü, İzmir, Yüksek Lisans Tezi, $98 \mathrm{~s}$.

Baba, A., 2000. Muğla-Yeniköy termik santral katı atıklarının çevre jeolojisi açısından incelenmesi. Türkiye 8. Enerji Kongresi, Ankara, 247-258. 
Baran, H.A., Sever, T., Ermin, M.V., Değirmenci, A. 2016. Coğrafi Bilgi Sistemleri ile maden haritalarının olușturulması: Güneydoğu Anadolu örneği. Batman Üniv. Yaşam Bilimleri Dergisi, 6(1), 13-26.

Dereli, M.A., Yalçın, M., Erdoğan, S. 2010. Madencilik faaliyetlerinde Coğrafi Bilgi Sisteminin kullanımı. Harita Teknolojileri Elektronik Dergisi, 2(3) 28-34.

Doğan, T., Özkan, M., Özer, Ü., Kapar, K., Kahriman, A., Erçelebi, S., 2007. Coğrafi Bilgi Sistemlerinin (CBS) rezerv tespitinde kullanılabilirliği. İstanbul Üniv. Müh. Fak. Yerbilimleri Dergisi, 20(2), 81-91.

Ketris, M.P., Yudovich, Y.E., 2009. Estimations of clarkes for carbonaceous biolithes: world averages for trace element contents in black shales and coals. International Journal of Coal Geology, 78, 135-148.

Malkoç, C., 2010. Tunçbilek ve Soma maden kömürü sahalarında çalışan işçilerde iş kazaları ve meslek hastalıkları görülme sıklığı ve ilişkili etmenler. Gazi Üniversitesi Sağlık Bilimleri Enstitüsü, Ankara, Yüksek Lisans Tezi, 119 s.

http://www.enerji.gov.tr/tr-TR/Sayfalar/Komur (Erişim tarihi: Şubat 2018)

Özkan, G., Yılmaz, O.S., Yalpır, Ş., 2007. Maden Bilgi Sistemi oluşturma çalışmaları. TMMOB Harita Mühendisleri Odası Ulusal Coğrafi Bilgi Sistemleri Kongresi Bildirileri, 30 Ekim-2 Kasim 2007, KTÜ, Trabzon.

Palmer, C.A., Tuncalı, E., Dennen, K.O., Coburn, T.C., Finkelman R.B. 2004. Characterization of Turkish coals: a nationwide perspective. International Journal of Coal Geology, 60, 85115.
Seyis, C., Yalçın, N.K., İnan, S., 2002. Coğrafi Bilgi Sistemine dayalı jeolojik veri tabanı yönetimine Zonguldak bölgesinden bir örnek. Türkiye 13 Kömür Kongresi Bildiriler Kitabı, 29-31 Mayıs 2002, Zonguldak, 335-346.

Sütçü, E., Paker, S., Nurlu, P., Kumtepe, P., Cengiz, T., 2009. Tekirdağ-Malkara havzasında CBS yöntemleriyle potansiyel kömür sahalarının belirlenmesine yönelik iki değişkenli istatistiksel yaklaşım. TMMOB Coğrafi Bilgi Sistemleri Kongresi Bildirileri, 02-06 Kasım 2009, İzmir.

Şalap, S., Karslıoğlu, M.O., Demirel, N., 2009. Development of a GIS-based monitoring and management system for underground coal mining safety. International Journal of Coal Geology, 80(2), 105-112.

Türkiye Linyit Envanteri, 2010. Maden Tetkik Arama Enstitüsü envanter eserisi - 202, Ankara, 371 s.

Ülger, N.E., Güneş, T.K., Akkaya, U.G., Kahriman, A., 2006. İstanbul bölgesi taşocakları bilgi sisteminin oluşturulması. İstanbul Üniv. Mühendislik Fakültesi Yerbilimleri Dergisi, 19(1), 51-61.

Ünalan, G., 2010. Kömür jeolojisi. MTA Eğitim serisi-41, Ankara, $556 \mathrm{~s}$.

Yomralıoğlu, T., 2000. Coğrafi Bilgi Sistemleri: temel kavramlar ve uygulamalar. Seçil Ofset: İstanbul. $480 \mathrm{~s}$. 